\title{
Comments
}

\section{INTERFERENCE WITH THE RIGHT TO FREE MOVEMENT: STOPPING AND SEARCH OF VEHICLES}

In the recent case of Fernandez $v$. United States, ${ }^{1}$ Federal Immigration Officers set up a roadblock seventy-two miles north of the Mexican border on one of California's main highways-Route 101 . The officers were acting under authority of a federal statute ${ }^{2}$ which allows immigration officials to search for aliens within a "reasonable distance" of a border and pursuant to an admimstrative regulation ${ }^{3}$ which defines "reasonable distance" as 100 air miles. The mission of the officers was to apprehend aliens who might have slipped through the border or entered along the nearby coast. There are more than ten cities between the border and the checkpoint. The stretch of Route 101 serves more than a million local residents, many of whom travel it daily. In light traffic all northbound autos are stopped; in heavy traffic about four out of every 100 cars are stopped. The occupants are questioned for a brief period. Most cars are waved through, but if the officers become suspicious they order the car over to the side of the road for further questioning of the occupants.

The immigration officials stopped defendant's auto though they had no reason to believe that either the car or its occupant was violating any law. Fernandez, when asked whether he was a citizen, replied that he was a registered alien coming from Mexico. He was told to pull over for further questioning. The officer, while questioning him, smelled an odor coming from beneath the hood of the car. A fellow officer recognized it as marijuana. They ordered that the hood be opened, discovered a quantity of marijuana, placed Fernandez under arrest, made a further search of the car and his person and found additional evidence. The court, in affrrming the conviction for possession of narcotics, held: (1) that the regulation's definition of "reasonable distance" did not exceed the authority of the enabling legislation and, (2) that the stopping and search in this case did not violate the fourth amendinent. ${ }^{4}$

This is only one federal case based on only one federal statute. Yet given the criteria applied by this court anyone in the United States traveling within 100 miles of any border (including oceans), is subject to being stopped, questioned, and perhaps searched by immigration agents. The questioning period is likely to be more protracted for one who is a member of a recognizable mimority group, but no one is exenupt. Moreover stopping for immigration purposes is by no means unique; all persons, good citizens and criminals alike, who operate motor vehicles on the lighways and city streets of this country are likely at some time in their lives to have their auto stopped and possibly searched. It would appear that such activities raise serious constitutional questions. This Counment will seek to investigate these questions.

1321 F.2d 283 (9th Cir. 1963).

- 28 U.S.C. $\$ 1357$ (1958).

3 Administrative Regulations Implementing the Immigration and Nationality Act, 8 C.F.R. $\S 287.1$ (1958).

4 The second lolding is that a search may be made upon probable cause to believe an offense is being committed. The odor of marijuana provided probable cause here since the officer was also designated as a customs officer with a duty to confiscate contraband. 
A "right to free movement" is not mentioned in the United States Constitution. Although there was such a right mentioned in the Articles of Confederation, ${ }^{5}$ it was omitted by the drafters of the Constitution. The reason for omission is not clear, but Professor Chafee is of the opinion that since it is unlikely that the drafters would have either overlooked or wished to eliminate the provision, it is probable that they considered it to be included elsewhere in the Constitution. ${ }^{6}$ The best, though far from ideal, substitute for the "free movement" clause, at least until passage of the fourteenth amendment, was Article 1, Section 8 of the Constitution-the "commerce clause." Although there has been relatively little formal mention of the right to free movement, it is an accepted ideal in this nation as well as in foreign states. ${ }^{8}$

In the early case of Crandall $v$. Nevada ${ }^{9}$ the Supreme Court, invalidating a state tax on interstate passengers, did not invoke the commerce clause, but instead designated the right of free novement across the country and between all states as a right of national citizenship. In Edwards v. California ${ }^{10}$ the Court struck down a California statute restricting the right of certain persons, deemed indigent, to enter the state. The majority of five based its holding on the commerce clause but Justice Douglas, concurring, said, "The right to move freely from State to State is an incident of national citizenship protected by the privileges and immunities clause of the Fourteenth Amendment against state interference."11 Douglas cited an earlier case in which the Court said, "Undoubtedly the right of locomotion, the right to remove from one place to another according to inclination, is an attribute of personal hiberty, and the right, ordinarily, of free transit from or through the territory of any state is a right secured by the Fourteenth Amendment and by other provisions of the Constitution." 12

STOPPINGS

\section{A. Investigations and Arrests Based Upon Probable Cause}

The leading federal case on stopping and search of automobiles is Carroll $v$. United States. ${ }^{13}$ In that case the Supreme Court broadly stated that persons who are lawfully within the country and who are entitled to use the public highways have a right to free passage, without interruption or search, unless competent authorities have reason, amounting to probable cause, to believe that their vehi-

5 Article IV provided that inhabitants of each of these states (1) shall be entitled to all the privileges and immunities of free citizens in the several states; (2) and the people of each state shall have free ingress and egress to and froin any other state. CHAFEe, TrReE Humar RIGHTS IN THE CONSTITUTION OF 1787 at 184 (1956).

0 Id. at 185 .

7 Id. at 186.

${ }^{8}$ At the San Francisco conference which led to the formation of the United Nations, it was proclaimed that, "Everyone has the right to freedom of movement and residence within the borders of each state. [meaning 'nation']" Art. 13.1 The Universal Declaration of Human Rights (Dec. 1948). Reprinted in Chafee, Dgcuments of Fundamentat Human Righis 956 (1954).

973 U.S. (6 Wall.) 35 (1867).

10314 U.S. 160 (1941).

11 Id. at 178 .

12 Williams v. Fears, 179 U.S. 270,274 (1900) (dictunl).

13267 U.S. 132 (1924). 
cles are carrying contraband or illegal merchandise. Similar sentiment has been expressed in many cases since. ${ }^{14}$

In Carroll, Federal Prohibition agents recogmized the appellant's car on a road which they regularly patrolled. One of the agents had previously tried (and failed) to purchase whiskey from Carroll. They stopped and searched the car and found illegal alcohol, which defendant sought to suppress. The court severely narrowed its broad dictum and stated that automobiles present a special situation due to their high mobility and, therefore, an officer may stop and search a vehicle even if he has no grounds for an arrest. It applied the following test: "If the facts and circumstances before the officer are such as to warrant a man of prudence and caution in believing that the offense has been committed, it is sufficient."15 One writer explains the case in terms of the strong judicial desire during the 1920's and early 1930's to uphold the eighteenth amendment ${ }^{16}$ and the Volstead Act and that the trend since repeal of Prohibition has been to return to a more hiberal construction of the fourth amendment and a narrow construction of probable cause. ${ }^{17}$

In order to determine whether the facts and circumstances warrant a stopping it is necessary to distinguisl between stopping for "investigation" and making of an "arrest." An arrest is the taking of another into custody for the actual or purported purpose of bringing him before a court, body or official, or of otherwise securing the administration of the law..$^{18}$ There are four essential elements of an arrest: (1) a purpose to take the person into custody, (2) under a real or pretended authority, (3) with an actual or constructive seizure or detention of his person, (4) so understood by the arrestee. ${ }^{19}$ As has often been stated: "It is an important principle of our pohtical institutions that every person is entitled to immunity from arrest except by authority and for cause." 20 Several writers have pointed out that stopping a pedestrian or a driver cannot constitute a "technical" or "common law" arrest unless all of the above elements are present.21

Generally an "investigation" is characterized by the presence of authority and perhaps a slight detention, with the other two elements absent. In Green $v$. United States, ${ }^{22}$ police officers saw a known drug addict walking on the street with a

14 E.g., Henry v. United States, 361 U.S. 98 (1959) ; Brinegar v. United States, 338 U.S. 160 (1949); Wirin v. Horrall, 85 Cal. App. 2d 497, 193 P.2d 470 (1948); People v. Roache, 237 Mich. 215, 211 N.W. 742 (1927).

15 Carroll v. United States, 267 U.S. 132, 165 (1924). Justice McReynolds, dissenting, points out that possession of alcohol under the Volstead Act is a misdemeanor and thus the Court violated the common law rule which probibits an arrest for a misdemeanor not committed in the officers' presence (meaning view).

16 This amendment prohibited the manufacture, sale or transporting of heverage liquors within the United States. (Repealed by Amendment XXI, Dec. 5, 1933).

1722 So. CAL. L. Rev. 181 (1949).

18 Restatearent, Torts $\$ 112$ (1934). A typical statute is Car. Pen. Code $\$ 834$ : "An arrest is taking a person into custody, in a case and in the manner authorized by law. An arrest may be made by a peace officer or by a private person." Perrins, Cases on Craminal LAW AND PROCEDURE 697 (1952) gives a similar definition.

${ }^{19}$ State ex rel. Sadler v. District Court, 70 Mont. 378, 225 Pac. 1000 (1924).

20 E.g., Snead v. Bonnoil, 166 N.Y. 325, 328, 59 N.E. 899, 900 (1901); State v. Sinall, 184 Iowa 882, 885, 169 N.W. 116, 117 (1918).

21 Perkins, The Law of Arrest, 25 Iowa L. Rev. 201, 207 (1940); 1960 WASk. U.L.Q. 279, 284. Justice McReynolds dissenting in Carroll v. United States, 267 U.S. 132, 169 (1924), held a different view and maintained that the very act of bringing the suspect within the officers' power constituted an illegal arrest. See Robertson v. State, 184 Tenn. 277, 198 S.W.2d 633 (1947), holding that the stopping of a car is an arrest even if it is only momentary in some cases.

22259 F.2d 180 (D.C. Cir. 1958), cert. denied, 359 U.S. 917 (1959). 
companion. The officers stopped to ask a few questions; the companion fled, was caught, searched, and drugs were found. In denying a motion to suppress the discovered evidence, the court held that it is not an arrest to ask questions of a known addict on a public street. The court pointed out that he could have declined to stop or talk and, if this had occurred, the police could have neither arrested nor searched him. The flight added the element of probable cause required for an arrest and search. In People v. Simon ${ }^{23}$ the court stated that there was nothing unreasonable in an officer's questioning persons outdoors at night even though he had no reason to suppose that they were involved in any kind of unlawful activity; ${ }^{24}$ and People v. Blodgett ${ }^{25}$ held that questioning of people seated in a double-parked taxicab at 3:00 a.m. was a reasonable investigation by a patrolman. ${ }^{26}$

In a recent case, People v. Mosco, ${ }^{27}$ the court explains that "the question of whether an officer has a right to interrogate the occupant of a vehicle is a separate issue froin whether he has the right to search and arrest the occupant."28 It goes on to say that California has consistently maintained that an officer may question a person outdoors at night when circumstances are such as would indicate to a reasonable nian in like position that such a course is necessary to the discharge of his duties. "The reasons required to permit an officer to properly engage in questioning are necessarily much less than would be required to permit arrest and search." 29

In Moore v. State, ${ }^{30}$ the appellant urged that he had been arrested by officers who stopped his car after observing it to be "going at a very slow rate of speed, and swerving or weaving back and forth across the road." The court held that a peace officer may nuake reasonable inquiry of persons when he observes or has knowledge of circumstances which reasonably suggest that a crime has been or is about to be committed. Several other Oklahoma cases have treated the stopping of an autonrobile as a reasonable investigation rather than an arrest. ${ }^{31}$

2345 Cal. 2d 645, 290 P.2d 531 (1955).

24 The holding was that the search was unjustified because the officer had no reasonable cause to go further than questioning the two suspects. An earlier California case, Gisske v. Sanders, 9 Cal. App. 13, 98 Pac. 43 (1908), upheld the propriety of "frisking" a citizen for weapons, even though lie was not under arrest. The court felt that a police officer liad a right to make proper inquiries of anyone on the public streets at a late hour if the surroundings are such as to indicate to a reasonable man that the public safety demands such identification. In Lee v. United States, 221 F.2d 29 (D.C. Cir. 1954), the court leeld that since the police had a tip that the suspect was attempting to sell jewelry on the street, they had a duty to investigate.

2546 Cal. 2d 114, 293 P.2d 57 (1956).

26 People v. Martin, 46 Cal.2d 106, 293 P.2d 52 (1956) (two men parked in "lovers' lane" fled upon seeing police; stopping for investigation justified); People v. Borbon, 146 Cal. App. 2d 315, 303 P.2d 560 (1956) (justifiable stopping of auto matching radio description of robbery suspect's car); People v. Martin, 140 Cal. App.2d 387, 295 P.2d 33 (1956) (investigation of car parked blocking beach access road at miglit is reasonable).

27214 A.C.A. 616, 29 Cal. Rptr. 644 (1963).

28 Id. at 619, 29 Cal. Rptr. at 646.

29 Id. at 620,29 Cal. Rptr. at 646.

30306 P.2d 358 (Okla. Crim. 1957).

31 Raper v. State, 96 Okla. Crim. 18, 248 P.2d 267 (1952) (automobile swerving onto shoulder and across center line); Robedeaux v. State, 94 Okla. Crim. 171, 232 P.2d 642 (1951) (car driving in erratic manner though slowly and carefully); Cainp v. State, 70 Okla. Crim. 68, 104 P.2d 572 (1940) (stopping of car and inquiry justified when police had seen package similar to stolen merchandise being loaded into it); see Hodge v. State, $97 \mathrm{Okla}$. Crim. 73, 258 P.2d 215 (1953) (driving on wrong side of the road); One 1948 Ford Tudor Automobile v. State, 207 Okla. 148, 248 P.2d 593 (1952) (erratic driving, failure to signal). 
In all of these cases there were some observable circumstances which could reasonably arouse the suspicions of an officer that a crime was then being, or about to be committed. ${ }^{32}$ But mere suspicion is not enough to warrant even an investigation. ${ }^{33}$ The courts are unanimous in their decisions that there is no precise formula as to what is sufficient to raise "mere suspicion" to the respectable level of "probable cause" for an investigation. Each case must be weighed on its own facts and circumstances.

In the well known case of United States v. Bonnano ${ }^{34}$ the New York State Police had information that a large group of known criminals, some of whom had come from as far away as Cuba and California, was meeting at the local estate of a convicted liquor violator. The police stationed themselves on the road outside the front gates of the estate and stopped several cars in order to question and identify the occupants. Two hours later, after seeing several men fleeing through the adjacent woods, the police began stopping all the cars and sending the occupants to the nearby police station where they were questioned briefly and released. In denying a motion to suppress evidence of what the pohice saw and heard, the court held that there was no unlawful arrest because there was no intent to hold the persons stopped. The court declared that the real issue is not whether a technical arrest occurred, but rather whether the police "procedures were of such a character that all evidence stemming from them must be suppressed."35

The doctrine which appears to emerge from the Bonnano case is that mere suspicion is enough to warrant investigation of a group of individuals who happen to have past criminal records and who drive away from a rural estate in the middle of the afternoon..$^{36}$ The court sets forth a list of requirements for stopping for investigation: (1) belief by the officer involved that a crime might have been committed, (2) reasonable grounds for such a belief and, (3) absolute necessity

32 Those factors which appear to be relevant in determining whether the investigation is reasonable are: A) late hour, B) disreputable neighborhood, C) information known to officers, and D) unusual conduct of suspects. Generally two or more of these factors have been present in those cases upholding the imvestigation, e.g., People v. Martin, 46 Cal. 2d 106, 293 P.2d 52 (1956), A, B, and D; People v. Blodgett, 46 Cal. 2d 114, 293 P.2d 57 (1956), A and D; People v. Simon, 45 Cal. 2d 645, 290 P.2d 531 (1955), A and B; People v. Witt, 159 Cal. App. 2d 492, 324 P.2d 79 (1958), C and D; People v. Jiminez, 143 Cal. App.2d 671, 300 P.2d 68 (1956), B, C, and D; People v. Martin, 140 Cal. App. 2d 387, 295 P.2d 33 (1956), A and D; Gisske v. Sanders, 9 Cal. App. 13, 98 Pac. 43 (1908), A and B ; Johnson v. Dist. of Columbia, 119 A.2d 444 (1956), A, C, and D; High v. State, 188 Tenn. 166, 217 S.W.2d 774 (1949), C and D. But, several investigations have been upheld on the basis of information only; see, e.g., Lee v. United States, 221 F.2d 29 (D.C. Cir. 1954); Green v. United States, 259 F.2d 18 (D.C. Cir. 1958); Poulas v. United States, 95 F.2d 412 (9th Cir. 1938); People v. Borbon, 146 Cal. App. 2d 315, 303 P.2d 560 (1956). When none of these factors is present the investigation is unreasonable. People v. Brown, 45 Cal. 2d 640, 290 P.2d 528 (1955); People v. Piazza, 15 App. Div. 2d 503, 222 N.Y.S.2d 548 (1961). (1951).

${ }^{33}$ E.g., People v. Piazza, sutpra note 32 ; Morrison v. State, 192 Tenn. 48, 237 S.W.2d 548

34 United States v. Bonnano, 180 F. Supp. 71 (S.D.N.Y.), rev'd on other grounds, 285 F.2d 408 (2d Cir. 1960).

35 Id. at 78. Professor Collings in Toward Workable Rules of Search and Seizure-An Amicus Catriae Brief, 50 CaL. L. REv. 421, 437 (1962), makes the same argument. As the Bonnano court mentions, it is possible to construe the fourth amendment to include "seizure of an individual." But, Professor Collins argues that even if stopping of an automobile is a seizure of person, the constitutional issue is not whether there was an arrest with or without reasonable cause, but whether the seizure of person was imreasonable.

3635 NOTRE DaATE LaW. 446 (1960). 
for immediate investigatory activity. ${ }^{37}$ One may question, however, whether the court's decision complies with these criteria. There was no apparent distinction made between the two hours of police investigation carried on before the observed flight through the woods and the investigation carried on after the flight. ${ }^{38}$ This amounts to saying that the reasonable belief that a crime (conspiracy) might have been committed was properly based upon the single known fact that some criminal overlords were in a house. ${ }^{39}$

Although the federal courts are quite similar to the state courts in recognizing the distinction between investigation and arrest, ${ }^{40}$ there is some conflict in the opinions ${ }^{41}$ and the distinction is not fully developed in some of the cases. ${ }^{42}$ There is a marked difference in result between cases where the transport of contraband is the crime, ${ }^{43}$ and those where a suspect is stopped on suspicion of violating a federal statute which does not involve contraband.44 United States v. Di $R e^{45}$ emphasizes the special nature of cases such as Carroll and Husty v. United States ${ }^{40}$ where the automobile was a necessary tool in implementing the crime and was actually treated like a criminal. ${ }^{47}$ In the general federal statute area there is less necessity for stoppings, and therefore one might expect the balance to swing towards the fullest possible protection of the right to privacy guaranteed by the fourth amendment.

37180 F. Supp. at 80.

38 Ibid.

39 The court gave considerable weight to the fact that the appellants all submitted to the investigation voluntarily. But it has been argued that the very presence of officers of the law, representing authority, giving orders, and asking questions produces, in the very nature of things, something less than a voluntary submission. Gilliam v. United States, 189 F.2d 321, 327 (6th Cir. 1951) (dissenting opinion).

40 Gilliam v. United States, 189 F.2d 321 (6th Cir. 1951); Weathershee v. United States, 62 F.2d 822 (5th Cir. 1933).

11 Gilliam v. United States, supra note 40 , at 327. Justice McAllister in his dissent reasons that the officers bere, unlike Carroll, had only vague suspicions. He says that, "the compulsion exercised by them [federal agents] in depriving hin of his freedom of proceeding along the public lighway, constituted an arrest... [R] estraint of another's freedom of locomotion by words, acts, or the like, which would induce a reasonable apprehension that force would be used unless he submitted, constitutes an arrest."

42 One source of this confusion is in Henry v. United States, 361 U.S. 98 (1959), where FBI agents saw a suspect's car, followed it, and watched while he loaded some packages, and then drove away and returned for more packages. They stopped and searched the car and found stolen radios. The Court beld that a prudent man under the circumstances would not have seen enough to give him reasonable cause to helieve that a felony was being committcd. Thus "When the officers interrupted the two men and restricted their liberty of movement, the arrest, for purposes of this case, was complete." Id. at 103.

The case is confusing because the government conceded that an arrest was made when the car was halted.

43 Brinegar v. United States, 338 U.S. 160 (1949) ; Husty v. United States, 282 U.S. 694 (1931); Carroll v. United States, 267 U.S. 132 (1924).

44 Clay v. United States, 239 F.2d 196 (5th Cir. 1956), cert. denied, 355 U.S. 863 (1957). Clay, a known gambler, was followed by federal agents. He fled, was pulled over and searched. Evidence of gambling was found on his person. The court held that an autonobile is not an automatic invitation for a stopping and search. The officers must have: 1) a good faith belief that a felony las been committed and, 2) probable cause for that belief. Here the flight was not enough to supply probable cause because there was nothing prior to flight save Clay's prior record.

45332 U.S. 581, 587 (1948).

46282 U.S. 694 (1931).

47 The Volstead Act provided for seizure and impounding of the offending vehicle. National Prohibition Act § 26, 41 Stat. 305 (1919). 


\section{B. Stoppings Without Probable Cause}

\section{Federal Customs and Immigration}

When customs officers make border stoppings and searches the safeguards of the fourth amendment are very much relaxed. No probable cause is needed to search persons entering the country. ${ }^{48}$ Moreover, customs officers need not inspect all incoming vehicles, but may search them more or less at random. ${ }^{49}$ The term "border search" is something of a misnomer because it is unusual that the inspection station is exactly on the border. ${ }^{50}$ In Ramirez $v$. United States, ${ }^{51}$ appellant was stopped at an immigration and customs station 75 miles north of the border in a desolate region. The appellant conceded that there was a right to search for aliens but objected to a customs search of luggage. The court held that the station was "of necessity, somewhat removed from the border," but this could be construed as a "point of entry." 52 This doctrine unay be applicable to aircraft whose point of entry is frequently well within the country, but it appears to be highly questionable as applied to automobiles. While it may well be necessary to permit random searches of autos at the border itself in order to insure that contraband does not enter the country illegally, it is also important that such procedures be strictly confined to a stopping and search in the immediate border area only.

The Immigration Department also has authority to stop persons ${ }^{53}$ and automobiles without probable cause. ${ }^{54}$ The blanket coverage of Regulation 287.1, which was applied in Fernandez, gives officers authority to stop all persons within 100 air miles of any external border. Stopping and searcli for ahens may very well be reasonable: (1) at the border, ${ }^{55}$ or (2) so near the border that it is reasonably clear that the car came from the border, ${ }^{56}$ and was not stopped at the border, ${ }^{57}$ or could not have been stopped elsewhere, ${ }^{58}$ or (3) where strong probable cause is shown. ${ }^{59}$ But on its face the constitutionality of Regulation 287.1 is certainly open to doubt because it provides that a stopping is reasonable regardless of the circumstances. ${ }^{60}$ The court in Fernandez listed the following reasons for sustaiming

48 Murgia v. United States, 285 F.2d 14 (9th Cir. 1960), cert. denied, 366 U.S. 977 (1961).

49 Ibid. In Witt v. United States, 287 F.2d 389 (9th Cir.), cert. denied, 366 U.S. 950 (1961), mere suspicion was enough to justify an intensive search. Here the appellant was stripped nude, narcotics were found, and the evidence was not suppressed.

50 Murgia v, United States, 285 F.2d 14 (9th Cir. 1960).

61263 F.2d 385 (5th Cir. 1959).

62See Plazola v. United States, 291 F.2d 56 (9th Cir. 1961) (stopping and search sixty to seventy miles north of border cannot be justified as a border search); Contreras v. United States, 291 F.2d 63 (9th Cir. 1961) (stopping seventy-two miles north not a border search).

53 Amaya v. United States, 247 F.2d 947 (9th Cir. 1957), cert. denied, 355 U.S. 916 (1958).

84 Statutes cited notes 2-3 supra.

85 Witt v. United States, 287 F.2d 389 (9th Cir.), cert. denied, 366 U.S. 950 (1961).

56 Kelly v. United States, 197 F.2d 162 (5th Cir. 1952).

57 Haerr v. United States, 240 F.2d 533 (5th Cir. 1957).

68 Ramirez v. United States, 263 F.2d 385 (5th Cir. 1959).

69 Murgia v. United States, 285 F.2d 14 (9th Cir. 1960), cert. denied, 366 U.S. 977 (1961). In Fernandez, the appellant argued that Congress only provided for one search at one point and that "reasonable distance" was meant to apply to cases where, for some good reason, there were no check points on the border. Brief for Appellant p. 4 .

${ }^{60}$ The court in Fernandez cites Kelly v. United States, 197 F.2d 162 (5th Cir. 1952), to rebut the contention that 287.1 is unconstitutional. Though it is true that in that case all occupants of all vehicles on the highway were questioned, the case is distinguishable in that the highway in question was the only road out of the isolated Florida Keys. In Fernandez the highway served one of the west coast's most populous regions. 
the immigration check: (1) the checkpoint was only one-quarter mile from the ocean; (2) Los Angeles has a large Mexican population and naturally attracts Mexicans; (3) Route 101 is the main artery from Mexico; (4) Los Angeles is a transportation center with air and rail service to all parts of the nation; (5) the history of the area over the past 31 years shows that many aliens have used this route. All these criteria go to the nature of the region and its history. ${ }^{01} \mathrm{An}$ argument, that a particular geographical area has such a notorious history that individuals' rights must be suspended as a matter of necessity, has never before been successful. ${ }^{22}$ If it were successful the courts would, in effect, be postulating something which might be labeled a "chronic emergency" as a basis for continuing roadblocks in populous areas. This is an obvious contradiction in terms as well as an unjustifiable reason for invading freedom of movement and privacy.

\section{Drivers' License Roadblocks}

City of Miami v. Aronovitz ${ }^{63}$ illustrates a situation in which the basis for stopping all cars at a roadblock was something like "general probable cause." city introduced statistics to prove that a given percentage of all cars in the area were being driven by unlicensed persons or by persons with suspended or revoked licenses. The stopping of a former mayor of Miami at a roadblock was based upon authority of the state's drivers' license "display" statute. ${ }^{65}$ The Florida law, like most display statutes, ${ }^{66}$ did not specifically authorize the police to stop cars but merely made display of a license a duty of the motorist. It is obviously difficult to imagine many situations where the police could have probable cause to believe the driver is unlicensed. ${ }^{67}$ Recognizing this, the court held that the roadblock was a proper use of the police power and was necessary as a means of promoting highway safety. Commonwealth v. Mitchell ${ }^{68}$ states that operation of an automobile is a privilege, not a right, and that this privilege is subject to reasonable police regulation. Moreover, the court states that an implied agreement of display is

${ }^{61}$ Appellant, in oral argument, pointed out that practically every major metropolitan area in the country falls within the area covered by regulation 287.1. For example, if we apply the court's criteria to the City of San Francisco: 1) the Bayshore Frecway is in some places less than one-quarter mile from the bay; 2) San Francisco has a large Chinese population; 3) the Bayshore is the main artery along the nearby coast and harbor areas; 4) San Francisco is a major transportation center; 5) it is well known that Chinese have been entering illegally through the San Francisco area for the past sixty years. Thus, it would appear reasonable to set up a checkpoint on the Bayshore to check for illegal aliens. All autos could be stopped at slack periods, and in busy hours four out of 100 cars could be "spot checked." Persons of Chimese ancestry might be pulled over for additional questioning.

62 See Contreras v. United States, 291 F.2d 63 (9th Cir. 1961) and Wirin v. Horrall, 85 Cal. App. 2 d 497, 193 P.2d 470 (1948), where the argument was unsuccessfully made.

63114 So. 2 d 784 (Fla. 1959).

64 Note, 1960 WaSH. U.L.Q. 279, 282 ; see 6 WAYNe L. Rev. 417 (1960).

65 FLA. STAT. ANN. $\$ 322.15$ (1961).

66 For an annotation of these statutes see 1960 WASH. U.L.Q. 279.

${ }^{67}$ Several cases are reported where the officers did know that the driver was unlicensed, but where arguably the arrest was used as a subterfuge to enable them to conduct a scarch. People v. Foote, 207 Cal. App. 2d 860, 24 Cal. Rptr. 752 (1962); Edwards v. State, 319 P.2d 1021 (OkJa. Crim. 1958); Branson v. State, 270 P.2d 362 (OkJa. Crim. 1954); Robertson v. State, 184 Tenn. 277, 198 S.W.2d 633 (1947); Cox v. State, 181 Tenn. 344, 181 S.W.2d 338 (1944). 
made when the hicense is accepted. ${ }^{69}$ In a Mississippi case, ${ }^{70}$ an officer had been flagging down and checking the hicenses of all drivers. He failed to flag down the appellant's car and gave chase in order to check the hicense. The court held that it was a proper exercise of the police power to flag down cars and check drivers' licenses, but that it was unreasonable to chase and stop a motorist without probable cause to believe he is unlicensed.

In summary, it seems that the use of roadblocks to check licenses is not unreasonable. The inconvenience experienced by the individual motorist is relatively slight while the benefits to be derived by enforcement of strict hicensing laws is relatively great. Furthermore, since there cannot be observable indications of a licensing law violation, stopping is the only practical method of enforcement. Although it might be argued that a violation of immigration law is no more observable than violation of a licensing statute, the two are distinguishable. The licensing law is a safety measure which applies to all roads within the state, and violation is as likely in one place as another. Althouglı unregistered aliens may be scattered througlout the state, it seems unreasonable to stop and search autos at random outside the immediate border areas because there are other less objectionable and more effective means of alien control such as working paper requirements. No doubt, there are obvious possibilities of abuse by law enforcement authorities in license checks, but that is no reason to nullify the practice. It does appear that the systematic stopping of all cars is apt to be less conducive to abuse than would be a practice of arbitrarily stopping any one car. Too often the inotive for stopping a single car would be other than to make a routine license check. ${ }^{71}$

\section{Other Stopping Situations}

A state law enforcement officer may stop vehicles and issue citations for violation of numerous provisions of the state vehicle code. Generally the officer will lave witnessed the violation, and there can then be no question that he has authority to stop and usually to arrest ${ }^{72}$ the offender. In any event, the mere issu-

69 This "implied agreement" could be used as a means of completely abrogating all right to privacy and freedom of movement in an automobile but for the further language of the court indicating that it would not allow a display stopping to be used as a subterfuge to make illegal searches. $I d$. at $68 \%$.

The implied agreement doctrine has been used in Tennessee in the area of fish and game control. TENN. CODE ANN. $\$ 51-701$ (1951), makes the possession of a hunting license a privilege which is granted in return for a waiver of the hunter's constitutional rights to be free and protected from unreasonable searches. See Monroe v. State, 194 Tenn. 519, 253 S.W.2d 734 (1952); State v. Hall, 164 Tenn. 548, 51 S.W.2d 851 (1932). In most states probable cause is required to stop an automobile in order to enforce fish and game laws. See, e.g., People v. Hill, 131 Misc. 521, 227 N.Y. Supp. 285 (1928).

70 Gause v. State, 203 Miss. 377, 34 So.2d 729 (1948).

71 Perhaps it would be advisable to amend the display statutes to make general roadblocks specifically permissible, but to make a license check other than at a duly constituted roadblock permissible only pursuant to some other lawful stopping such as issuance of a moving violation citation.

${ }^{72}$ CAL. PEN. CODE $\$ 836$ is a typical arrest statute permitting a peace officer to make an arrest: 1) with a warrant, or 2) without a warrant, a) when he has reasonable cause to believe that the person to be arrested has committed a public offense in his presence, $b$ ) when a person arrested has committed a felony though not in his presence, or c) when he has reasonable cause to beheve that the arrestee has committed a felony whether or not a felony has in fact been committed. See CAL. VEH. CODE $\$ \$ 40301-305$ which, under certain conditions, require an officer to take persons guilty of a vehicle misdemeanor before a magistrate, e.g., if driver fails to exhibit a valid license, if he refnses to promise to appear, or if he is a nonresident with no local address. See also Arrest Authority in Traffic Cases. TRAFric Digest \& REvIEw (Feb. 1956), reprinted in DoNIGAN \& FISHER, KNow THE LAW 219 (1958). 
ance of a traffic citation has, despite some opinion to the contrary, ${ }^{73}$ regularly been held to be an invitation to appear and the stopping is not deemed an arrest. ${ }^{74}$ Other state safety measures which have been uniformly upheld include the stopping of trucks for weighing ${ }^{75}$ and the stopping of automobiles for safety checks. ${ }^{76}$ No case has been found considering the validity of stoppings for agricultural inspection, traffic census, or quarantine regulations, but it is unlikely that any valid objection could be raised to reasonably conducted procedures of this type.77

Perhaps the most well known use of roadblocks is the cordon tactic (blocking of all roads) used to apprehend a criminal who is believed to be in a specific area. The justification for using this extreme tactic seems to be the necessity to prevent escape. ${ }^{8}$ There have been several cases upholding the cordon when there has been a particular crime known to the authorities who reasonably believe the criminal to be in the vicinity. ${ }^{79}$ But how extreme can the measures be and how great must be the necessity? In Wirin v. Horrall, ${ }^{80}$ a Los Angeles taxpayer questioned the tactics of the police who were blocking off designated areas and stopping and searching all automobiles and persons without any probable cause save the general nature of the neighborhood (the crime rate was relatively high). On one occasion an area of six blocks was blockaded. All persons were stopped, many were searched, fingerprinted and taken into custody. Another time police blocked seven intersections with approximately 200 officers from 9:00 p.m. until midnight. In holding that the complaint stated a cause of action, the court emphasized that

73 Sherry \& Cotzings, The LAw of ARrest, Searce and Setzure 3 (6th rev. ed. 1961).

74 Barrier v. Alexander, 100 Cal. App. 2d 497, 224 P.2d 436 (1950) (no arrest made when summons issued); City of Toledo v. Lowenberg, 99 Ohio App. 165, 131 N.E.2d 682 (1955) (subsequent appearance in traffic court was voluntary and no restraint or detention existed). See also Berry v. Bass, 157 La. 81, 102 So. 76 (1924); People v. Yerman, 138 Misc. 272, 246 N.Y.S. 665 (1930). See generally Perkins, The Lawe of Arrest, 25 Iowa L. REv. 201 (1940); Issuance of Traffic Citation Not An Arrest, TrafFic Digest \& REvIEw (May 1956), reprinted in DONIGAN \& FisHeR, KNow THE LAW 222 (1958).

75 Brinegar v. United States, 338 U.S. 160 (1949) (dicta); Commonwealth v. Abel, 275 Ky. 802, 122 S.W.2d 757 (1939); People v. Fidler, 280 App. Div. 698, 117 N.Y.S.2d 313 (1952). See, CAL. Ver. Code $\$ \S 2802,2803,2806$; Perkins, The Lave of Arrest, 25 Iowa L. REv. 201, 207 (1940).

${ }^{76}$ See Brinegar v. United States, 338 U.S. 160, 188 (1949) (dissenting opinion); Busby v. United States, 296 F.2d 328 (9th Cir. 1961), cert. denied, 369 U.S. 876 (1962); People v. Sanson, 156 Cal. App. 2d 250, 319 P.2d 422 (1957). Generally the display statutes fall into three categories: 1) a few requiring no probable cause to stop a motorist in any case-see, e.g., Iowa CGDE ANN. \$ $321.492(1943), 2)$ a considerable number granting police the power to stop and inspect cars which they reasonably believe to be operating with defective equipment-see, e.g., Artz. Rev. Stat. ANn. § 28-982A (Supp. 1962), 3) some allowing officers to stop a motorist upon reasonable behef that his equipment is defective or that any other provisions of the code are being violated-see, e.g., N.C. GEN. Stat. \$ 20-49(d) (1953).

77 Brinegar v. United States, 338 U.S. 160, 188 (1949) (dissenting opinion). Cf. Perkins, supra note 75 , at 207 . Perhaps these interruptions im free travel might be reconciled with the mandate of Crandall v. Nevada, 73 U.S. (6 Wall.) 35 (1867), and Carroll v. United States, 267 U.S. 132 (1924), by strictly limiting these activities to the safety aspect.

78 It has been suggested that the reasonableness of such tactics might be influenced by the heinousness of the crime. It was said that a cordon is a drastic and undiscrininating use of search but that perhaps a kidnapping is the type of crime which might warrant its use. Brinegar v. United States, 338 U.S. 160, 183 (1949) (Jackson, J., dissenting).

70 Pcople v. Euctice, 371 IIl. 159, 20 N.E.2d 83 (1939); Commonwealth ex rel. Crawford v. Bollinger, 198 Ky. 646, 249 S.W. 786 (1923); Freedman v. State, 195 Md. 275, 73 A.2d 476 (1950); State v. Hatfield, 112 W.Va. 424, 164 S.E. 518 (1932).

8085 Cal. App. 2d 497, 193 P.2d 470 (1948). 
the guarantees of the fourth amendment could not be treated liglitly. ${ }^{81}$ A San Diego sheriff's roadblock at the Tijuana border was the victim of another California decision. ${ }^{82}$ It was held that the possibility that criminal use is being made of a car cannot justify stopping and searching all autos in hopes of finding some criminals. ${ }^{83}$

There are no reported cases on the use of roadblocks during periods of excessive drinking, such as New Year's Eve. ${ }^{84}$ It would seem that this enforcement technique is more analogous to the exploratory search situation than to the known crime situation. ${ }^{85}$ Professor Collings suggests that perhaps holiday roadblocks are justifiable on the theory of the riglit to make automobile safety cliecks. ${ }^{86}$ It is arguable that some sort of "general probable cause" might be created by the statistical proportion of drunks known to be on the highways. The particular holiday time-period might provide the immediacy required for a reasonable investigation of automobiles. One distinguishing factor is the ease with which a license check may be made. The driver need merely display his license. Conversely, a drunk check often involves reflex and coordination tests which are both time consuming and humiliating. Furthermore, drunk driving, unlike license violations, is often detectable by observable activity-erratic driving. ${ }^{87}$

81 "Following . . . Horrall the California attorney general in an [unpublished] opinion dated Feb. 23, 1949 advised the California Highway Patrol that the decision . . . in no manner restricted the authority of the ... Patrol to stop a vehicle being operated upon a highway and require the driver thereof to display his drivers' license ...." He advised that the stopping need not "be based on reasonable cause to believe that the vehicle, its contents, or the operator are in violation of the law. The authority to inspect gives authority to stop." Road Blocks: Right and Wrong, TrafFic Digest \& REview (Aug. 1956), reprinted in DONIGAN \& FisHer, KNOW THE LAW 238, 244 (1958).

82 People v. Gale, 46 Cal.2d 253, 294 P.2d 13 (1956). The officers stopped Gale's car, noticed recent fender damage, ignored the driver's explanation that it had been damaged a month earher in Los Angeles, ordered him out, searched the car, and found narcotics. The officer testified that the purpose of the roadblock was "to curb the juvenile problem and also check for . . anything suspicious." Id. at 255,294 P.2d at 14.

$83 \mathrm{Id}$. at 256,294 P.2d at 15 . The attempt of the officers to justify the stopping as a reasonable investigation on suspicion of hit-run driving was unsuccessful. The court reasoned that such violations are relatively rare. Furthernuore, even if the damage did justify the stopping, a consistent answer (as was given) gave no further basis for detention.

84 The San Francisco Examiner, Feb. 16, 1957, p. 7, col. 5, reports the dismissal of the case of People v. Rowe in the Sacramento Superior Court. It was stipulated that Rowe was arrested when his car was stopped at a New Year's Eve traffic check. The reason given for dismissal was that the police had no legal right to stop the car in order to observe the driver's condition, and thus, the evidence had to be suppressed.

85 Generally, an exploratory searcl is one in which the officers do not have any specific information or knowledge but are observing everyone (innocent and guilty alike) waiting for a crime to occur. A notorious example is provided in the recent California case of Bielicki v. Superior Court, 57 Cal.2d 602, 371 P.2d 288, 21 Cal. Rptr. 552 (1962), where police spied through a pipe above a public toilet hoping that if they watched long enough they might witness hounosexual activity. The case is noted in 63 ColUM. L. REv. 955 (1963), where it is pointed out that protection under the fourth amendinent seems to have shifted from a viewpoint oriented towards protection of property rights to a desire to protect the individual's right to privacy.

86 Collings, supra note 35 , at 435 . He also suggests that the use of roadblocks and publicity about their use would deter drunks from driving.

$87 \mathrm{~A}$ few states have passed statutes which specifically authorize law enforcement authorities to unaintain temporary roadblocks for designated purposes (usually appreliension of escaping criminals). IDAHo COdE ANN. \$\$ 19-620-19-623 (Supp. 1963) ; Mont. Rev. Code ANN. $\S \S 94-6029-94-6033$ (Supp. 1963); Nev. REv. Stat. $\$ 484.220$ (1961). See 24 Mont. L. Rev. 137 (1963). 


\section{II}

\section{SEARCH INCIDENT TO A VALID STOPPING}

\section{A. General Rules}

Given a valid stopping by state or federal authorities, when may a search be made and what may be searched for? The fourth amendment does not prohibit all searches, only those which are unreasonable. ${ }^{88}$ Its protection has been extended to include business offices, ${ }^{80}$ stores, ${ }^{00}$ apartments, ${ }^{01}$ hotel rooms, ${ }^{, 2}$ public rest rooms, ${ }^{93}$ automobiles, ${ }^{94}$ and taxicabs. ${ }^{95}$ Evidence procured in violation of the fourth or fourteenth amendments must be excluded by all courts, state as well as federal. ${ }^{96}$ Moreover, a recent decision may require that state courts apply federal reasonableness standards. ${ }^{97}$ The courts have recognized several situations in which a search may be made incident to arrest with or without a warrant. These include instances where search is necessary: for protection of the officer and deprivation of means of escape, ${ }^{98}$ for prevention of destruction of evidence by the arrestee, ${ }^{20}$ or due to high mobility of vehicles making hesitation impractical.100 Indeed it can no longer even be said that officers must always obtain a search

88 Carroll v. United States, 267 U.S. I32 (1924). Of course, voluntary consent to a search acts as a waiver of the right to object. Campbell v. United States, 151 F.2d 605 (6th Cir. 1945). See 51 CAITF. L. REV. (1963). It should also be noted that the act of picking up material thrown from a car constitutes neither a search nor a seizure. Murgia v. United States, 285 F.2d 14 (9th Cir. 1960), cert. denied, 366 U.S. 977 (1961); Lee v. United States, 221 F.2d 29 (D.C. Cir. 1954).

89 Gouled v. Umited States, 255 U.S. 298 (1921); Silverthorne Lumber Co. v. United States, 251 U.S. 385 (1920). See United States v. Rabinowitz, 339 U.S. 56 (1950).

90 Amos v. United States, 255 U.S. 313 (1921). See Davis v. United States, 328 U.S. 582 (1946).

91 Jones v. United States, 362 U.S. 257 (1960).

02 United States v. Jeffers, 342 U.S. 48 (1951).

93 Biehicki v. Superior Court, 57 Cal. 2d 602, 371 P.2d 288, 21 Cal. Rptr. 552 (1962).

94 Henry v. United States, 361 U.S. 98 (1959) ; Brinegar v. United States, 338 U.S. 132 (1949); Gambino v. United States, 275 U.S. 310 (1927); Carroll v. United States, 267 U.S. 132 (1924).

95 Rios v. Umited States, 364 U.S. 253 (1960) ; People v. Blodgett, 46 Cal. 2d 114, 293 P.2d 57 (1956).

96 Mapp v. Ohio, 367 U.S. 643 (1961).

${ }^{97}$ Ker v. California, 83 Sup. Ct. 1623 (1963). The opmion is confusing but Justice Harlan is of the opinion that federal reasonableness standards now apply to the states.

98 Busby v. United States, 296 F.2d 328 (9th Cir. 1961) (shotgun observed) ; Pcople v. Jiminez, 143 Cal. App.2d 671, 300 P.2d 68 (1956) (furtive moveinent); People v. Watkins, 19 Ill. 2d 11, 166 N.E.2d 433 (1960) (flight) ; People v. Gonzales, 356 Mich. 247, 97 N.W.2d 16 (1959) (pistol observed) ; Closson v. Morrison, 47 N.H. 482, 93 Am. Dec. 459 (1867) (escape); Duncan v. State, 191 Tenn. 427, 234 S.W.2d 835 (1950) (a known "dangerous man"); State v. Hatfield, 112 W.Va. 424, 164 S.E. 518 (1932) (pistol ohserved).

09 People v. Blodgett, 46 Cal. 2d 114, 293 P.2d 57 (1956) (furtive movement); People v. Anders, 167 Cal. App. 2d 65, 333 P.2d 854 (1959) (package thrown out of auto); Pcople v. Sanson, 156 Cal. App. 2d 250, 319 P.2d 422 (1957) (furtive movement).

100 Carroll v. United States, 267 U.S. 132 (1924); Morrison v. State, 192 Tenn. 48, 237 S.W.2d 548 (1951). 
warrant when practicable; 101 vahdity is now dependent upon the reasonableness of the search under the circumstances. ${ }^{102}$

The federal courts in a line of cases starting with Carroll $v$. United States have created an exception to ordinary search and seizure rules whereby an automobile may be stopped and searched if probable cause exists to believe that an offense is being committed. ${ }^{103}$ Patenotte v. United States ${ }^{104}$ lists five criteria relevant to establish probable cause to search vehicles: (1) reputation of, or informant reports concerning the occupants, (2) a like reputation of the vehicle or owners, (3) the condition of the vehicle (e.g., lieavily loaded), (4) information from reliable informers as to the existence and purpose of the illegal trip, and (5) the reputation of the location in which they are found..$^{105}$ Similar standards liave been used by state courts, ${ }^{106}$ and have been applied to the actions of state officers who work with federal revenue agents. ${ }^{107}$

Since the repeal of Prohibition, many federal cases dealing with auto searches have been concerned with customs and immigration. It is true, as was indicated above, that an immigration search may be conducted at some distance from the border. ${ }^{108}$ But when a customs search is conducted at a considerable distance from a border in a populous area, as in Cervantes $v$. United States, ${ }^{109}$ probable cause is required. In that case it was leeld that information given to customs officers ten weeks prior to the date of the search could not provide probable cause. The information, along with the appellant's prior criminal record, justified a thorough

101 Trupiano v. United States, 334 U.S. 699 (1948) (overruled by United States v. Rabinowitz, 339 U.S. 56 (1950)).

102 United States v. Rabinowitz, supra note 101 at 66 . The Court points out that the reasonableness of each case turns on its own particular facts and circunistances. In Rabinowitz the search was: 1) incident to a valid arrest, 2) in a public place, 3 ) in the inmediate control of the arrestee. The search was for contraband the possession of which is a crime justifying seizure. Despite Rabinowitz, failure to obtain a warrant when practicable is still a relevant factor in deternining reasonableness of a search. Chapman v. United States, 365 U.S. 610 (1961) (Court held search of whiskey still illegal though officers smelled nash cooking and search was made on Sunday); Morrison v. State, 192 Tenn. 48, 237 S.W.2d 548 (1951).

103 Most state courts also follow this rule. See, e.g., People v. Foote, 207 Cal. App. 2d 860, 24 Cal. Rptr. 752 (1962). Contra, Brinegar v. State, 97 Okla. 299, 302, 262 P.2d 464, 467 (1953), refusing to apply the rule because it breaks down the common law differentiation between arrest for a suspected felony and arrest for a suspected misdeneanor.

104266 F.2d 647, 650 (5th Cir. 1959). Federal revenue agents, recognizing a truck as one owned by a previous hquor violator, stopped and searched it and found contraband.

105 Other federal cases apply these criteria. Husty v. United States, 282 U.S. 694 (1931) (information, known bootlegger, flight); Carroll v. United States, 267 U.S. 132 (1924) (known bootlegger, bootlegging territory); McCarthy v. United States, 264 F.2d 473 (8th Cir. 1959) (seen at known whiskey supplier, heavy load, bootlegging territory); Smith v. United States, 264 F.2d 469 (8th Cir. 1959) (information, heavy load, dirty car with clean license plates); Gilliaun v. United States, 189 F.2d 321 (6th Cir. 1957) (information, known bootlegger in bootlegging territory, appellant showed officers a whiskey jar) ; Poulas v. United States, 95 F.2d 412 (9th Cir. 1938) (information, admission by defendant).

106 E.g., Edwards v. State, 319 P.2d 1026 (Okla. Crim. 1957).

107 United States v. Cotter, 80 F. Supp. 590 (E.D. Va. 1948). In a rather extrene example, one state court held that where a niagistrate could not issue a warrant, the sheriff could not niake a vehicle search without one. Elardo v. State, 164 Miss. 628, 145 So. 615 (1933).

108 See text accomipanying notes 50-52 supra.

109278 F.2d 350 (9th Cir. 1960). The search was conducted at the Route 101 inimigration checkpoint seventy-five miles north of the Mexican border. This was the second indictment on this charge. In the first action the government also failed to maintain its burden of proving probable cause. Cervantes v. United States, 263 F.2d 800 (9th Cir. 1959). 
border search, but a second stopping 72 miles within the country was unwarranted. ${ }^{110}$ Thus, even in customs searches, as necessity and immediacy decrease, probable cause requirements increase.

If probable cause to search exists, the permissible scope of the search will depend upon the nature of the material being sought. Officers may search an automobile which they reasonably believe contains contraband, but the right to search a car does not confer any right to search a mere occupant (other than the person in charge of it). ${ }^{111}$ Nor may a vehicle be searched without either a warrant or probable cause to arrest when the reason for the Carroll exception-the danger that the auto may leave the vicinity or jurisdiction-is absent. Thus when the driver is under arrest and the car held in custody, ${ }^{112}$ or when the car is no longer on the streets, ${ }^{113}$ no search may be made without a warrant because there is no element of necessity present.

In Haerr v. United States ${ }^{114}$ the defendant conceded the propriety of an immigration check conducted fourteen miles above the border. But the court went on to comment by way of dictum: "Such a procedure might also reasonably involve examination of any personal property in their possession as well as all parts of the car including the trunk."115 This seems clearly contrary to other immigration cases such as Contreras $v$. United States, ${ }^{110}$ holding illegal a search by immigration officers of a paper sack observed on the front seat, or United States $v$. Hortze $^{117}$ in which it was held that a search of a cigarette package at an alien checkpoint was unreasonable. In the latter case the court explains that immigration officers while examining a place where aliens might hide (such as a luggage conpartment) need not close their eyes to evidence of other crimes. Conversely, in the absence of "a search warrant or probable cause, individuals ought not be delayed in their travels along the boundaries of our country, nor their effects disturbed, to an extent not necessary for the conduct of a bona fide search for ahens ...."118 It appears that the practice of designating immigration officers as customs officials may lead to an understandably overzealous attitude and its byproduct-unreasonable searches. ${ }^{110}$ Even if a second stopping to catch aliens is permissible, it does not follow that a second search for customs violations may also be conducted, nor should this practice be tolerated unless probable cause to search exists.

110278 F.2d at 353 . Probable cause will still be found if the time lag is only a few days. Draper v. United States, 358 U.S. 307 (1959).

111 United States v. Di Re, 332 U.S. 581 (1948).

112 Rent v. United States, 209 F.2d 893 (5th Cir. 1954). However, some state court cases, which allow officers to nuake an inventory of a car in custody, appear to sanction what amounts to a thorough search without a warrant. E.g., People v. Baker, 135 Cal. App. 2d 1, 286 P.2d 510 (1955); State v. Olsen, 43 Wash. 2d 726, 263 P.2d 824 (1953).

113 Boyd v. State, 206 Miss. 573, 40 So.2d 303 (1949) (car in garage). Butt of. Scher v. United States, 305 U.S. 251 (1938) (car driven into garage to avoid search after chase).

114240 F.2d 533 (5th Cir. 1957).

$115 \mathrm{Id}$. at 535 . (Emphasis added).

110291 F.2d 63 (9th Cir. 1961).

117179 F. Supp. 913 (S.D. Cal. 1959).

$118 \mathrm{Id}$. at 918.

110 The practice might be more reasonable in cases such as Ramiriz v. United States, 263 F.2d 385 (5th Cir. 1959), where the geographical area is such that no border station is feasible. 


\section{B. The "Search Incident to a Valid Arrest" Rule}

The desire of courts to provide law enforcement authorities with some uniform standards of search and seizure has led to the oft quoted, ${ }^{120}$ and oft questioned ${ }^{121}$ maxim that a search may automatically be conducted incident to a lawful arrest with $^{122}$ or without ${ }^{123}$ a warrant. Particularly in the area of minor traffic violations this is indeed a harsh rule. It is unquestioned by several courts that if the arrest, though lawful, is made purely as a subterfuge to allow the officers to make a search, the search is illegal and the fruits are inadmissable. ${ }^{124}$ But the difficulties in proving that the arrest was a mere subterfuge are obvious. Furthermore, there are numerous cases in which the courts have refused to make an analysis in order to determine whether subterfuge was present. General searches have been upheld incident to arrests for speeding, ${ }^{125}$ defective lights, ${ }^{126}$ lack of driver's license, ${ }^{127}$ lack of license tags, ${ }^{128}$ lack of title certificate, ${ }^{129}$ and running a stop light. ${ }^{130}$ In all of these cases the search was permitted as properly incident to a lawful arrest though there were no facts to show that the officers were warranted in searching for weapons nor could evidence of the violation have been found in the vehicle. ${ }^{131}$

Cahifornia is one of a number of jurisdictions which does not permit an automatic search incident to any arrest. ${ }^{132}$ Oklahoma is also one of these jurisdictions and Brinegar v. State, ${ }^{133}$ an Oklahoma decision, is probably the most carefully reasoned opinion in this area. Brinegar, a known bootlegger, was observed driving erratically at miglit. Officers halted his car, searched the immediate area of the driver's seat for weapons, found whiskey in the glove compartment, made an arrest, searched the trunk, and found more whiskey. The court explains that no matter what the basis for an arrest, a subsequent search is always judged by the

120 United States v. Rabinowitz, 339 U.S. 56, 63 (1950) ; People v. Foote, 207 Cal. App. 2d 860, 864, 24 Cal. Rptr. 752, 755 (1962); People v. Watkins, 19 Ill. 2d 11, 18, 166 N.E.2d 433, 436 (1960).

121 People v. Molarius, 146 Cal. App.2d 129, 303 P.2d 350 (1956) ; People v. Zeigler, 358 Mich. 355, 100 N.W.2d 456 (1960); People v. Gonzales, 355 Mich. 247, 97 N.W.2d 16 (1959). See Note, 1959 WIs. L. Rev. 347, 359; 49 Irr. B.J. 680, 682-83 (1960); 1960 U. IrL. L.F. 440, 443; 43 Kx. L.J. 163, 170-71 (1954); 6 WAXNE L. REv. 413, 416 (1960).

122 United States v. Rabinowitz, 339 U.S. 56 (1950).

123 People v. Foote, 207 Cal. App. 2d 860, 24 Cal. Rptr. 752 (1962).

124 People v. Molarius, 146 Cal. App. 2d 129, 303 P.2d 350 (1956) (illegal U-turn); Courington v. State, 74 So.2d 652 (Fla. 1954) (drunk driver-search of trunk); People v. Zeigler, 358 Mich. 355, 100 N.W.2d 456 (1960) (running stop sign) ; Robertson v. State, 184 Tenn. 277, 213 S.W.2d 196 (1947) (driver's license clieck); Cox v. State, 181 Tenn. 344, 181 S.W.2d 338 (1944) (driver's license check). But see Cameron v. State, 112 So.2d 864, 869 (Fla. 1959) (driver's license check admitted subterfuge by suspicious officer).

125 People v. Davis, 247 Mich. 536, 226 N.W. 337 (1929).

126 State v. Deitz, 136 Wash. 228, 239 Pac. 386 (1925).

127 Rucker v. State, 225 Ind. 636, 77 N.E.2d 355 (1948).

128 Piland v. State, 162 Tex. Crim. 362, 285 S.W.2d 230 (1955).

129 Smith v. State, 215 Ind. 629,21 N.E.2d 709 (1939).

130 Marsh v. United States, 29 F.2d 172 (2d Cir. 1928).

131 An arrest for driving while intoxicated would probably warrant a search for a bottle, but the search cannot extend outside the immediate reach of the driver. Courington v. State, 74 So.2d 652 (Fla. 1954).

132 People v. Molarius, 146 Cal. App. 2d 129, 303 P.2đ 350 (1956).

13397 Okla. Crim. 299, 262 P.2d 464 (1953). Oklahoma, due to its prohibition laws, has a considerable number of automobile cases. This opinion gives an extensive history of the prior case law. 
same standard-was it reasonable? Here it was held that no evidence of subterfuge was present and that the search for weapons was reasonable, but only because the officer had reasonable cause to fear for his own safety under the circumstances. ${ }^{134}$ The glove compartment, being a convenient place for firearms and within the immediate control of the driver, is fair game for a weapons search. The discovered whiskey gave reasonable cause to search the rest of the automobile for further contraband.

Just as there are reasonable himits on the permissible scope of the search of houses, ${ }^{135}$ apartments, ${ }^{136}$ or offices, ${ }^{137}$ it is submitted that there must be clearly defined limits on the scope of search incident to a traffic arrest. All will admit that the police officer's job is hazardous, particularly so in the stopping of an automobile late at night, but the "search incident to a lawful arrest" rule gives no guidance whatsoever and should be discarded in favor of the "reasonableness under the circumstances" test set out in Brinegar v. State.

\section{III}

\section{CONCLUSTON}

Although the automobile has many beneficial uses in our modern mobile society, it is also a source of potential destruction and death and is a highly efficient means of transporting escaping criminals and contraband. Because of this potential for misuse the ordinary rules of search and seizure have been modified so that law enforcement officers niay effectively protect all citizens. While there are some situations, such as custouns, immigration or auto safety checks, where free movement may be interrupted without specific probable cause, this is not, nor should it be, the general rule.

The special rules of auto search must always be apphed in each particular case by examining closely both the individual's rights to freedom and privacy and the "public interest" the state is seeking to protect. The danger is that rules and their exceptions tend to become dogma unless this careful examination takes place. In particular, rules such as "a search nuay be made incident to a lawful arrest" and "100 miles is a reasonable distance from an external border" remain useful only so long as they are guideposts to thinking through a particular set of events. When these rules become crutches to be used as a substitute for careful analysis they become worse than useless and must be discarded. As Justice Jackson emphasized, "an illegal search usually is a single incident, perpetrated by surprise, conducted in haste, kept purposely beyond the court's supervision and limited only by the judgment and moderation of officers whose interests and records are often at stake in the search."138 Continual re-examniation of the rules of auto search will assure that law enforcement activities do not result in abuse and injustice.

James $H$. Newhouse

134 See cases cited note 98 supra. A departmental policy to search all persons arrested for traffic violations would be invalid. Brinegar v. State, 97 Okla. 299, 315, 262 P.2d 464, 480 (1953) (dictum). As a practical matter it would be difficult to prove that no probable cause existed if the officer were to testify that le observed a furtive inovement or a suspicious bulge under the driver's coat.

135 Agnello v. United States, 269 U.S. 20 (1925) ; Drayton v. United States, 205 F.2d 35 (5th Cir. 1953).

136 Harris v. United States, 331 U.S. 145 (1947). Included is an excellent collection of search and seizure cases listed in chart form. Id. at 175 .

137 Umited States v. Lefkowitz, 285 U.S. 452 (1932).

138 Brinegar v. United States, 338 U.S. 160, 182 (1949) (dissenting opinion). 